\title{
Ks. Edmund Robek SAC, Kościołowi w Polsce powiedz... Refleksja teologicznopastoralna Warszawa 2009, s. 443
}

Liczne przemiany współczesnego świata stawiają przed człowiekiem, a także przed różnymi społecznościami czy wspólnotami wiele nowych rzeczywistości życiowych. Niekiedy spotkanie to jest ubogacające, czasem niszczące, a kiedy indziej stawia nowe pytania czy wyzwania.

Procesy te dotyczą także Kościoła jako społeczności nadprzyrodzonej oraz ziemskiej. Pielgrzymuje on bowiem w danym czasie, w ludzkiej rzeczywistości miejsca i konkretnych osób.

Znany pastoralista ks. prof. Edmund Robek SAC jest wykładowcą w Uniwersytecie Kardynała Stefana Wyszyńskiego w Warszawie. Jest autorem wielu prac, w tym kilku książek, m.in. Mitość zbawcza w Kościele i świecie (Warszawa 2007), Pallotyńskie apostolstwo mitości. Z okazji 100-lecia dziatalności Pallotynów w Polsce (Warszawa 2007), Drogi Kościota (Warszawa 2004).

Prezentowaną książkę otwiera Spis treści (s. 7-15) oraz Wykaz skrótów (s. 17$-18)$.

Natomiast treściowo wprowadza Wstęp (s. 19). Następnie całość podzielono na osiem rozdziałów. Pierwszy z nich nosi tytuł: Naukowa refleksja o codziennym wzrastaniu Kościoła (s. 21-60). Wskazano na jedność, wolność i miłość w Kościele Chrystusowym. W tym kontekście ukazano eklezjologię pastoralną i organizację działań wspólnoty kościelnej.

Współczesne duszpasterstwo organiczne to tematyka kolejnego rozdziału (s. 61-99). To głównie pytania o parafię, która rozpatrywana jest jako organiczna „wspólnota wspólnot”. Skazano także na współczesną parafię w Polsce w świetle charyzmatu pallotyńskiego.

Trzeci rozdział koncentruje się na temacie: Formy działalności duszpasterskiej (s. 101-159). To kwestia organicznego duszpasterstwa rodzin i jego praktycznych aspektów. Wskazano na duszpasterską opiekę nad ludźmi w podeszłym wieku oraz dialog międzypokoleniowy w duszpasterstwie młodzieży.

Caritas $w$ duszpasterstwie zaprezentowano w rozdziale czwartym (s. 161-189) wskazując najpierw na oblicza miłości w charytatywnej posłudze Kościoła. Caritas jawi się jako funkcja zbawcza Kościoła. W praktyce duszpasterskiej praca charytatywna przybiera wiele zróżnicowanych form.

Rozdział piąty analizuje rzeczywistość: Kościót pielgrzymujący (s. 191-252). Przybliżono tak w sferze teorii jak i praktyki duszpasterstwo pielgrzymkowe. 
Samo pielgrzymowanie jest drogą nawrócenia. Oddzielne wskazano na duchowość pielgrzymki do Ziemi Świętej.

W kolejnym rozdziale zaprezentowano Apostolat świeckich (s. 252-322). Autor przybliżył pastoralne aspekty apostolstwa świeckich oraz ukazał je w perspektywie duchowej. Wyakcentowano także teologicznopastoralny wymiar modlitwy.

Największa jest miłość jest tematyką rozdziału 7. (s. 323-352). Miłość jest drogą człowieka do wiary oraz do świętości. Przywołano jeszcze Maryję - Matkę miłości miłosiernej.

Ostatni rozdział opatrzono tytułem: Współczesny świat (s. 353-408). Wybrzmiewa tutaj humanizm chrześcijański jako współczesne wyzwanie dla Kościoła. Także ważna jest siła pokoju oparta na prawdzie. W końcu ukazano Jana Pawła II jako obrońcę praw człowieka.

Całość treściową książki zamyka krótkie Zakończenie (s. 409). Natomiast od strony formalnej dodano jeszcze Aneks (s. 411-424) i Bibliografię (s. 425-443).

Prezentowane opracowanie ukazało się jako trzeci tom serii „Biblioteka Teologii Pastoralnej” wydawanej przez Polskie Stowarzyszenie Pastoralistów i Duszpasterzy im. Jana Pawła II. Ta edycja związana jest z Sekcją teologii pastoralnej UKSW.

Oto stosunkowo szerokie tematycznie opracowanie. Dotyka ono wielu interesujących kwestii pastoralnych. W wielu miejscach jest to jednak propozycja interdyscyplinarna. Trudno bowiem oddzielić liczne elementy praktyczne od teoretycznych, a te dotykają np. teologii moralnej czy duchowości.

Jak zaznacza autor we Wstępie „z (...) potrzeby służenia Kościołowi powstała również ta książka. Zawiera ona część dorobku pastoralisty, który przez dwadzieścia lat zbierał doświadczenia duszpasterskie, a przez ostatnie kilkanaście lat poświęcił się naukowej pracy, za cel której przyjął poszukiwanie możliwości łączenia mądrości płynącej z doświadczenia z wynikami badań naukowych. Autor tej książki stara się odkrywać przed Czytelnikiem bogactwo polskiej, teologicznopastoralnej myśli. Niemniej ważne jest jednak, aby jej treść stała się dla Czytelnika inspiracją do własnych poszukiwań oblicza Kościoła, który żyje, myśli, czuje, kocha, wzbudza nadzieję, podtrzymuje wiarę, daje siły, prowadzi człowieka do źródła życia wiecznego" (s. 19)

Wydaje się, że udało się autorowi wskazać na wiele interesujących kwestii pastoralnych. Jawią się one w formie dość komunikatywnej, co wynika - jak się wydaje - właśnie z długoletniego praktycznego doświadczenia duszpasterskiego. Oczywiście, może to rodzić pytania czy wątpliwości co do jednorodności prezentowanego opracowania.

W zakończeniu autor wskazuje, że „tytuł tej książki: Kościotowi w Polsce powiedz... sugeruje, że ta refleksja teologicznopastoralna nie jest zakończona. Każdy uczeń Chrystusa jest powołany do służenia Kościołowi, ale jego zadaniem jest 
również poznawanie Kościoła. Najlepszym sposobem zdobywania mądrości kościelnej jest dialog. Materiały zamieszczone w tej książce są tylko "głosem» w tej dyskusji na temat Kościoła" (s. 409)

To jest owa cenna świadomość teologa pastoralisty. Owo otwarcie się jest dobrą perspektywą oraz może budzić nadzieje. Oby od powiedzenia udało się jak najszybciej przejść do podejmowanych działań, które w wielu miejscach sugeruje sam autor, ale narzucają się one w osobistej refleksji.

Zamieszczona bibliografia została usystematyzowana według pewnego schematu. Wydaje się, że przynajmniej część nauczania papieży ma większą wartość doktrynalną i teologiczną niż Dokumenty kościelne. Zapewne z przyczyn technicznych nie zachowano w literaturze przedmiotowej porządku alfabetycznego. Spotkać można błędy literowe, zwłaszcza w wyrazach obcojęzycznych. Błędy te dotyczą tak bibliografii jak i przypisów.

W całości opracowania, nie tylko w fragmentach wprost wskazanych, wybrzmiewa duchowość oraz nachylenie duszpasterskie palotyńskie. Jest to bowiem pewna oferta, którą autor zweryfikował już w latach pracy duszpasterskiej. Zresztą, przywołuje te doświadczenia ze znaczną osobistą satysfakcją.

Bp Andrzej F. Dziuba 